\title{
Understanding the Technostress: An Individual Difference Investigation
}

\author{
Myung-Seong Yim \\ Dept. of Business Administration, Sahmyook University \\ 기술스트레스에 대한 이해: 개인 차이에 대한 연구 \\ 임명성 \\ 삼육대학교 경영학과
}

\begin{abstract}
This research extends the research stream of technostress by incorporating age and gender as moderators of user perceptions in the workplace. Individual reactions toward technostress were studied throughout the past decade. However, changing demographic patterns have led to an increasingly older workforce. Gender effects in individual reactions toward technological stress differ based on age. Specifically, gender differences in technology perceptions became more pronounced among older workers, but a unisex pattern of results emerged among younger workers. The results from this study suggest that the factors of technostress is changed by gender and age. In light of these findings, theoretical and practical implications for researchers and practitioners are discussed.
\end{abstract}

Key Words : Technostress, Gender Difference, Social Role Theory

요 약 본 연구의 목적은 기술스트레스에 관련된 기존의 연구에서 인구통계학적 측면에서 나이와 성별에 대한 개인 간 차이가 발생하는지 살펴보고자 수행되었다. 기술스트레스에 대한 개인의 반응은 이미 오랫동안 연구되어왔다. 하 지만 변화하는 인구통계학적 패턴이 기존 연구에서 반영되지 않은 경우가 많았다. 특히 업무현장에서 정보기술은 개 인별 특성에 의해 깊이 관련이 있기에 관련 연구가 필요하다. 연구 결과 기술스트레스의 구성 요인들은 나이와 성별 에 따른 차이를 나타내는 것으로 확인되었다.

주제어 : 기술스트레스, 테크노 스트레스, 성별 차이, 사회 역할 이론

\section{Introduction}

Stress is a cognitive response that individuals experience when they anticipate their inability to respond adequately to perceived demands of a given situation, accompanied by anticipation of negative

Received 4 December 2013, Revised 10 January 2014 Accepted 20 March 2014

Corresponding Author: Myung-Seong Yim

(Sahmyook University)

Email: msyim@syu.ac.kr

ISSN: $1738-1916$ consequences for inadequate response [20][23]. Thus, stress is a psychological reaction to some sort of an imbalance between a person and the environment [20]. Tecnostress relates to the phenomenon of stress experienced by employees in many organizations as a result of their use of ICTs (Information and (C) The Society of Digital Policy \& Management. All rights reserved. This is an open-access article distributed under the terms of the Creative Commons Attribution Non-Commercial License (http://creativecommons.otg/licenses/by-nc/3.0), which permits unrestricted non-commercial use, distribution, and reproduction in any medium, provided the original work is properly cited. 
Communication Technologies) [20]. Indeed, computerization of the office work environment is shown to have higher levels of stress among employees [2]. ICTs can create stress in a number of ways, because the ability of humans to handle information is limited [22]. First, their capabilities for constant connectivity extend the regular work day which, in turn, blur the home and work contexts, creating difficulty in maintaining work-life balance. Second, mobile device such as laptops, smart phones, and tablet PC have made it routine for employees to simultaneously handle different streams of information from internal and external sources, rushing to process whatever information is available online. Third, technical capabilities and terminology associated with ICTs have become more complex. Finally, organizations adopt ICT products and applications that change rapidly [20][25]. The effects of technostress leads to one's discomposure, fear, hostility, anxiety, and resistance when one is learning and using computer technology directly or indirectly [22][29].

Over the past decade, changing demographic patterns have led to an increasingly older workforce. While demographic differences have been interested in information systems fields, there has been relatively little research on the influence of demographic differences on technostress in an organizational context. Yet there is some evidence that demographic characteristics have an important influence on technostress in the workplace. For instance, Wang et al. (2008) assert that gender, age, and education level are related to technostress. Thus, it is important to investigate the effects of these individual level variables. However, little empirical research has tested these relationships. Thus, it appears that gaining a better theoretical understanding of gender and age differences is important. Taking a cross-sectional approach with data gathered from 635 individuals in a field setting, this research attempts to achieve following primary objective: an individual difference investigation for understanding the technostress. Thus, we seek to explain how technostress varies across individuals.

In summary, this paper extends the aforementioned research to investigate the existence of significant differences among men and women in terms of technostressors of employees. Social role theory affords us a theoretical framework in which to study such gender differences in terms of technostress research stream. Drawing form social role theory, our study investigates the neglected context of gender and position differences using constructs that are theoretically and empirically linked to technostressors.

\section{Literature Review}

\subsection{Social Role Theory}

The primary theoretical guide for our research is rooted in social role theory, which proposes that viewing people in various social roles provides an important basis for beliefs about social groups [17] The theory explains why gender differences vary across types of behavior [12]. According to the theory, women and men show different social behaviors because of different societal and cultural expectations for the two genders [10]. Social role theory emphasizes the causal impact of gender roles-that is, of people's beliefs about the behavior that is appropriate for each gender [10].

Previous studies in information technology (IT) have mainly focused on differences in usage of various IT artifacts by men and women [8]. The behaviors of women are greatly dependent on interpersonal relationships, whereas the behaviors of men tend to focus heavily on outcome [8]. Thus, women focus on cooperation, intimacy, friendships, and efforts to maintain harmonious relationship, whereas men emphasize competitiveness due to the differing social expectations across gender. That is, men and women 
are more comfortable with behaviors that are consistent with their identity [19].

Additionally, males may have greater ability to provide career assistance because of their stature in the company [19]. A major reason for interest in the role of gender is that many key positions in organizations are held by males. Agentic relationships are associated more with men because of their position of greater power within organizations [19].

We suggest that social and cultural norms affect how employees in organization react toward technological stress. Thus, technostress is a serious issue for the users and IT professionals due to its potential effect on users' mental health and on-the-job productivity [28]. However, technostressors are different for every professional; individual responses are also different [7]. According to Brod (1982), important variables affecting the technostress are age, past experience with technology, perceived control over new tasks, and etc. That is, demographic characteristics will represent different reactions to technostress. Thus, in order to understand whether levels of technostress are equal across various organizational characteristics, we examined two demographic variables such as gender and hierarchical level of the respondent.

\subsection{Technostress}

As the use of computers moves up in the organization, and computers are designed for increasingly complex tasks, human performance will depend on how effectively employees can operate the machines [5]. However, machines have produced a new set of problems. These may be intellectual, psychological, physical or social [3]. These include adjustments to constantly evolving ICTs and the changing physical, social, and cognitive requirements related to ICTs use [24].

The term technostress was first coined in 1984 by clinical psychologist Craig Brod in his book
Technostress: The Human Cost of the Computer Revolution [2][22]. Technostress refers to a condition resulting from the inability of an individual or organization to adapt to the introduction and operation of new technology [5]. The term is called, variously, technophobia, cyberphobia, computer phobia, computer anxiety, computer stress, terminal paralysis, negative computer attitudes, and other similar terms [3][29]. Technostress has a negative impact on work productivity and turnover by shifting attention from work-congruent stress to internal states of distress; resulting in behavior that limits the usefulness of technology [5][21][27]. Technostress occurs in circumstances where employees perceive their job as stimulating at the same time as they feel that they do not quite master the necessary skills [1]. The primary symptom of those who are ambivalent, reluctant, or fearful of computers is anxiety [4]. This anxiety is expressed in many ways such as headaches, nightmares, irritability, and resistance to learning about the computer or outright rejection of the technology [4].

Technostress creators can be regarded as five different aspects or dimensions of technostress such as techno-overload, techno-invasion, techno-complexity, techno-insecurity, and techno-uncertainty [20]. Techno-overload is associated with situations where information communication and technologies (ICTs) force users to work faster and longer [20]. Techno-invasion refers to the invasive effect of ICTs in situations where employees can be reached anytime and feel the need to be constantly connected, thus blurring work-related and personal contexts [20]. Techno-complexity describes situations where the complexity associated with ICTs leads users to feel inadequate with regard to their computer skills and forces them to spend time and effort in learning and understanding ICTs [20]. Techno-insecurity describes situations where users feel threatened about losing their jobs, either because of automation from ICTs or to other people who have a better understanding of 
ICTs [20]. Techno-uncertainty is associated with contexts where continuing ICT changes and upgrades unsettle users and create uncertainty so that they must constantly learn and educate themselves about new ICTs [20].

$<$ Table $1>$ Profile of Respondents

\begin{tabular}{|c|c|c|c|}
\hline & & Frequency & Ratio \\
\hline \multirow[t]{2}{*}{ Gender } & Male & 485 & 76.4 \\
\hline & Female & 150 & 23.6 \\
\hline \multirow[t]{5}{*}{ Age } & 18 to 24 & 4 & 0.6 \\
\hline & 25 to 34 & 271 & 42.7 \\
\hline & 35 to 44 & 239 & 37.6 \\
\hline & 45 to 54 & 105 & 16.5 \\
\hline & 55 above & 16 & 2.5 \\
\hline \multirow{5}{*}{$\begin{array}{c}\text { Education } \\
\text { Level }\end{array}$} & High School & 30 & 4.7 \\
\hline & Two-year college & 38 & 6.0 \\
\hline & Bachelor's degree & 413 & 65.0 \\
\hline & Master's degree & 144 & 22.7 \\
\hline & Doctorial degree & 10 & 1.6 \\
\hline \multirow[t]{7}{*}{ Position } & Technical & 104 & 16.4 \\
\hline & Administrative/Clerical & 285 & 44.9 \\
\hline & Professional Staff & 53 & 8.3 \\
\hline & Middle Manager & 155 & 24.4 \\
\hline & Senior Manager & 23 & 3.6 \\
\hline & Sales & 15 & 2.4 \\
\hline & Total & 635 & 100 \\
\hline
\end{tabular}

\section{Research Method}

\subsection{Sample and Data Collection}

The survey instrument of this research is based on the technostress quenstionnaire developed by Tarafdar et al. (2007). This questionnaire has been translated from English into Korean. All items in the questionnaire are measured on a 7-point Likert type scale, with 1 indicating "strongly disagree" and 7 indicating "strongly agree". Respondents were asked to circle the appropriate number to indicate the extent to which he/she agreed or disagreed with each statement. Twenty three items were used to measure technostress.

The survey was distributed a random sample of 800 employees in 82 organizations in Korea. A total of 728 questionnaires were completed representing a 0.91\% response rate. We carefully checked these questionnaires and removed the ones that are incomplete. A total of 635 usable questionnaires were used in the following analysis. Among the 635 respondents, 28\% are at management level, and the rest are employees; about $76.4 \%$ are male, and the rest are female.

\subsection{Exploratory Factor Analysis and Reliability}

Factor analysis is an analytic technique that permits the reduction of a large number of interrelated variables to a small number of latent or hidden dimensions [26]. The goal of factor analysis is to achieve parsimony by using the smallest number of explanatory concepts to explain the maximum amount of common variance in a correlation matrix [26]. In order to achieve this goal, this study conducted exploratory factor analysis (EFA) with maximum likelihood extraction method. If the goal is to arrive at the parsimonious representation of the associations among measured variables, EFA can be an appropriate form of analysis [11]. EFA is based on the common factor model. This model postulates that each measured variable is a battery of measured variables is a linear function of one or more common factors and one unique factor [11]. The goal of the common factor model is to understand the structure of correlations among measured variables by estimating the pattern of relations between the common factors and each of the measured variables [11]

Before conducting EFA, we evaluate the overall measures of intercorrelation to ensure that the data matrix has sufficient correlations to justify the application of factor analysis [13]. To do this, two measures were evaluated: the Bartlett's test of sphericity and the measure of sampling adequacy (MSA). Bartlett's chi-square test evaluates the amount of information in the correlation matrix, given the 
$<$ Table 2> Exploratory Factor Analysis

\begin{tabular}{|c|c|c|c|c|c|c|c|c|}
\hline & & \multicolumn{5}{|c|}{ Factor } & \multirow{2}{*}{$\begin{array}{c}\text { Commu }^{-} \\
\text {nality }\end{array}$} & \multirow{2}{*}{$\begin{array}{c}\text { Cronbach's } \\
\text { Alpha }\end{array}$} \\
\hline & & \multirow{2}{*}{$\frac{1}{016}$} & \multirow{2}{*}{\begin{tabular}{|c|}
2 \\
.911
\end{tabular}} & \multirow{2}{*}{$\begin{array}{c}3 \\
.032 \\
\end{array}$} & \multirow{2}{*}{\begin{tabular}{|c|}
4 \\
-.007
\end{tabular}} & \multirow{2}{*}{$\begin{array}{c}5 \\
-.018 \\
\end{array}$} & & \\
\hline \multirow{4}{*}{$\begin{array}{l}\text { Techno- } \\
\text { overload }\end{array}$} & TS1 & & & & & & .829 & \multirow{4}{*}{.916} \\
\hline & TS2 & .012 & .963 & -.026 & -.055 & -.004 & .880 & \\
\hline & TS3 & .013 & .946 & -.024 & .001 & -.002 & .892 & \\
\hline & TS4 & -.011 & .546 & .054 & .110 & .064 & .416 & \\
\hline & TS7 & -.004 & .099 & -.042 & -.069 & .740 & .588 & \\
\hline $\begin{array}{l}\text { lecnno- } \\
\text { invasion }\end{array}$ & TS8 & .052 & -.038 & .037 & -.031 & .846 & .699 & .788 \\
\hline & TS9 & .006 & -.001 & .015 & .145 & .589 & .442 & \\
\hline & TS10 & -.032 & .063 & -.034 & .805 & -.078 & .622 & \\
\hline Techno- & TS11 & .071 & -.056 & .048 & .842 & -.016 & .720 & \\
\hline complexity & TS12 & -.033 & .027 & -.093 & .620 & .147 & .487 & .845 \\
\hline & TS14 & .093 & .029 & .070 & .675 & .027 & .564 & \\
\hline Techno- $^{-}$ & TS18 & .990 & .038 & -.026 & .011 & -.020 & .999 & \\
\hline insecurity & TS19 & .764 & -.007 & .004 & .023 & .047 & .629 & .883 \\
\hline & TS20 & -.092 & .010 & .799 & .028 & .022 & .644 & \\
\hline Techno- & TS21 & -.033 & .003 & .868 & -.002 & .038 & .755 & 917 \\
\hline uncertainty & TS22 & .060 & .012 & .862 & -.042 & -.020 & .753 & .911 \\
\hline & TS23 & .056 & .000 & .896 & .002 & -.034 & .808 & \\
\hline Eigenvalue & & 5.648 & 3.280 & 1.790 & 1.323 & 1.100 & & \\
\hline$\%$ of Variance & & 33.226 & 19.297 & 10.529 & 7.783 & 6.472 & & \\
\hline Cumulative $\%$ & & 33.226 & 52.523 & 63.051 & 70.835 & 77.307 & & \\
\hline & & $\mathrm{KMO}$ & Bartlett' & & & & & \\
\hline Kaise & eyer-Olk & Measure & ampling & uacy. & & .849 & & \\
\hline & & & Approx & Square & & 7070.328 & & \\
\hline Bartlett's T & f Spheri & & Degree & reedom & & 136 & & \\
\hline & & & Sig & nce & & .000 & & \\
\hline
\end{tabular}

Extraction Method: Maximum Likelihood.

Rotation Method: Oblimin with Kaiser Normalization.

Rotation converged in 4 iterations.

relation between the number of observations and the number of variables [26]. The test indicates the probability of error in rejecting the null hypothesis of no deviation from an identity matrix [26]. A significant chi-square represents a minimum requirement for performing a factor analysis [26]. In this study, the Bartlett's test finds that the correlations are significant at the 0.0001 level (see Table 2). This test only indicates the presence of nonzero correlations, not the pattern of these correlations [13]. The MSA considers not only the degree of intercorrelations among the variables, but also their patterns between variables [13]. The MSA can be interpreted with the following guidelines: 0.80 or above, meritorious; 0.70 or above, middling; 0.60 or above, mediocre; and 0.50 or above miserable. In this study, the measure falls in the acceptable range with a value of 0.849 .

A researcher must determine how large the sample should be and how that sample will be selected from the population of interest [11]. Evidence-based guidelines suggested by methodologists are that a sample size of 100 is poor; 200, fair; 300, good, 500, very good; and 1,000, excellent [16][26]. Unfortunately, there are serious drawbacks to such guidelines. One problem is that these guidelines do not consider the numbers and types of variables being analyzed [26]. Second, such guidelines are not sufficiently sensitive to a variety of important characteristics of the data [11]. Another rule for sample size is that the minimum is to have at least five times as many observations as the number of variables to be analyzed, and the more acceptable sample size would have at least 10 
기술스트레스에 대한 이해: 개인 차이에 대한 연구

$<$ Table 3> Descriptive Statistics (Gender)

\begin{tabular}{|c|c|c|c|c|c|c|c|c|c|}
\hline & \multirow[t]{2}{*}{$\mathrm{N}$} & \multirow[t]{2}{*}{ Mean } & \multirow[t]{2}{*}{ Std. Deviation } & \multirow[t]{2}{*}{ Std. Error } & \multicolumn{2}{|c|}{$\begin{array}{l}\text { 95\% Confidence Interval for } \\
\text { Mean }\end{array}$} & \multirow[t]{2}{*}{ Minimum } & \multirow[t]{2}{*}{ Maximum } \\
\hline & & & & & & Lower Bound & Upper Bound & & \\
\hline \multirow{3}{*}{ Overload } & 1.00 & 485 & 4.1737 & 1.36254 & .06187 & 4.0521 & 4.2953 & 1.00 & 7.00 \\
\hline & 2.00 & 150 & 3.9867 & 1.36679 & .11160 & 3.7661 & 4.2072 & 1.00 & 7.00 \\
\hline & Total & 635 & 4.1295 & 1.36478 & .05416 & 4.0232 & 4.2359 & 1.00 & 7.00 \\
\hline \multirow{3}{*}{ Invasion } & 1.00 & 485 & 3.6296 & 1.45218 & .06594 & 3.5000 & 3.7591 & 1.00 & 7.00 \\
\hline & 2.00 & 150 & 3.6022 & 1.31344 & .10724 & 3.3903 & 3.8141 & 1.00 & 7.00 \\
\hline & Total & 635 & 3.6231 & 1.41967 & .05634 & 3.5125 & 3.7337 & 1.00 & 7.00 \\
\hline \multirow{3}{*}{ Complexity } & 1.00 & 485 & 3.8345 & 1.26318 & .05736 & 3.7218 & 3.9472 & 1.00 & 7.00 \\
\hline & 2.00 & 150 & 3.8883 & 1.14931 & .09384 & 3.7029 & 4.0738 & 1.00 & 6.00 \\
\hline & Total & 635 & 3.8472 & 1.23656 & .04907 & 3.7509 & 3.9436 & 1.00 & 7.00 \\
\hline \multirow{3}{*}{ Insecurity } & 1.00 & 485 & 2.6990 & 1.34997 & .06130 & 2.5785 & 2.8194 & 1.00 & 7.00 \\
\hline & 2.00 & 150 & 2.6000 & 1.31077 & .10702 & 2.3885 & 2.8115 & 1.00 & 7.00 \\
\hline & Total & 635 & 2.6756 & 1.34045 & .05319 & 2.5711 & 2.7800 & 1.00 & 7.00 \\
\hline \multirow{3}{*}{ Uncertainty } & 1.00 & 485 & 5.0010 & 1.24430 & .05650 & 4.8900 & 5.1120 & 1.00 & 7.00 \\
\hline & 2.00 & 150 & 4.7183 & 1.23168 & .10057 & 4.5196 & 4.9171 & 1.00 & 7.00 \\
\hline & Total & 635 & 4.9343 & 1.24617 & .04945 & 4.8371 & 5.0314 & 1.00 & 7.00 \\
\hline
\end{tabular}

observations per variable [13]. In this study, we used 635 samples for analysis and met these two criteria.

There are several factor analysis extraction methods to choose from: unweighted least squares, generalized least squares, maximum likelihood, principal axis factoring, alpha factoring, and image factoring [9]. We chose the maximum likelihood (ML) method. $\mathrm{ML}$ is the best choice because it gives the best results, depending on whether data are generally normally distributed or significantly non-normal, respectively [9].
After selecting the extraction method, we decided how many factors to retain for rotation. The Kaiser's criterion which retains factors with eigenvalues greater than 1 is one of the most commonly used methods [14][16].

The next decision is rotation method. The goal of rotation is to simplify and clarity the data structure [9]. Direct oblimin method (oblique method) used to produce factors that are correlated because, realistically, few constructs in the real world are

$<$ Table $4>$ Descriptive Statistics (Position)

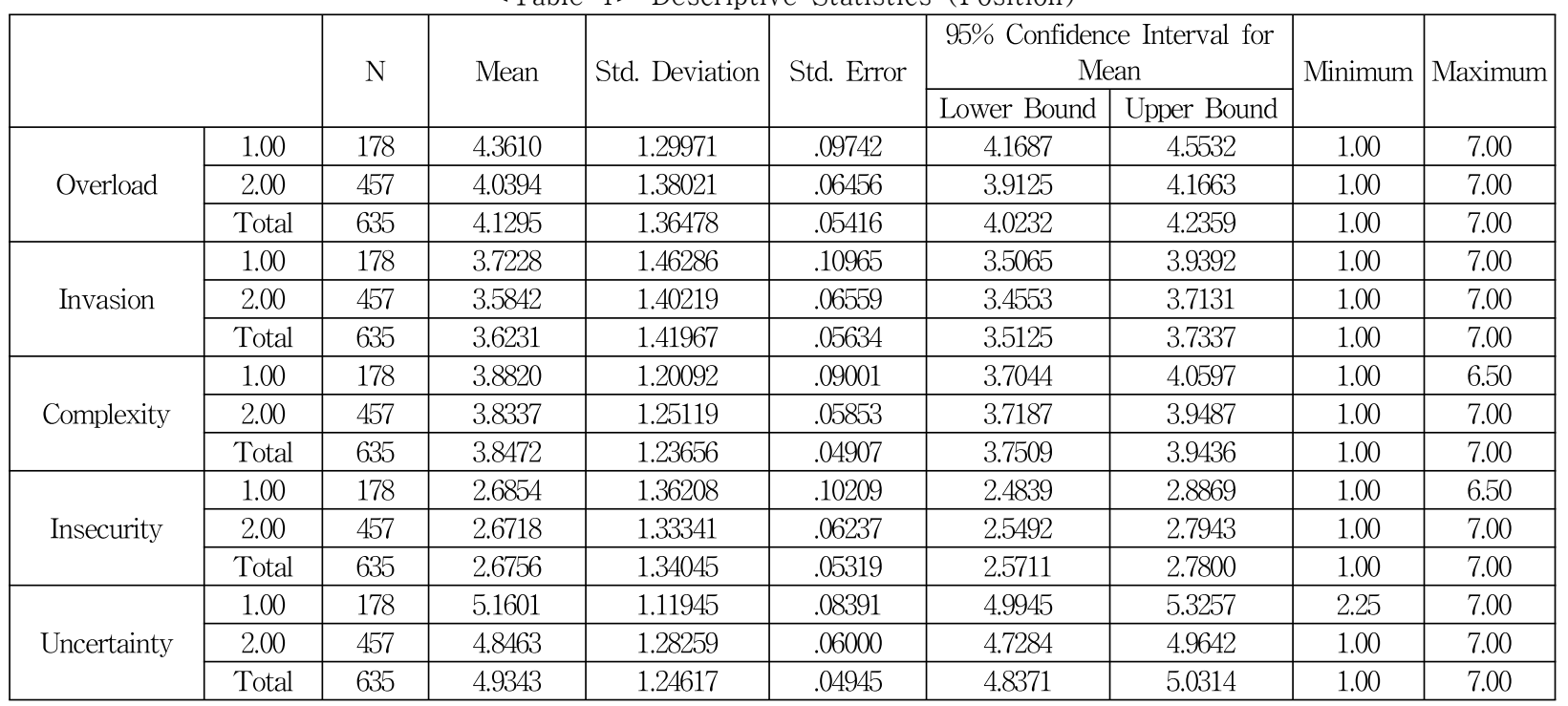


$<$ Table $5>$ Test of Homogeneity of Variances (Gender)

\begin{tabular}{|l|c|c|c|c|}
\hline & Levene Statistic & df1 & df2 & Sig. \\
\hline Overload & .012 & 1 & 633 & .912 \\
\hline Invasion & 2.767 & 1 & 633 & .097 \\
\hline Complexity & 2.486 & 1 & 633 & .115 \\
\hline Insecurity & .191 & 1 & 633 & .662 \\
\hline Uncertainty & .014 & 1 & 633 & .905 \\
\hline
\end{tabular}

$<$ Table $6>$ Test of Homogeneity of Variances (Position)

\begin{tabular}{|l|c|c|c|c|}
\hline & Levene Statistic & df1 & df2 & Sig. \\
\hline Overload & 1.538 & 1 & 633 & .215 \\
\hline Invasion & .307 & 1 & 633 & .580 \\
\hline Complexity & .230 & 1 & 633 & .632 \\
\hline Insecurity & .561 & 1 & 633 & .454 \\
\hline Uncertainty & 2.916 & 1 & 633 & .088 \\
\hline
\end{tabular}

uncorrelated [13]. Thus, using orthogonal rotation results in a loss of valuable information if the factors are correlated and oblique rotation could theoretically render a more accurate solution [9].

Although factor loadings of \pm 0.30 to \pm 0.40 are minimally acceptable, factor loadings of 0.50 or higher should be considered in the interpretation of a factor [13]. As shown in Table 2, all loadings are greater than 0.5 .

A crossloading item is an item that loads at 0.4 or higher on two or more factors. The researcher needs to decide whether a cross loading item should be dropped from the analysis. If there are several crossloaders, the items may be poorly written or the a priori factor structure could be flawed [9]. We couldn't find crossloadings which were higher than 0.40 .

The communality indicates the proportion of the total variance of a variable that is common variance [26]. While item communalities are considered high if they are all 0.8 or greater, this is unlikely to occur in real data [9]. According to rule-of-thumb considerations, the thresholds of communality are ranged from 0.40 to 0.70 [9]. In this study, all communalities are ranged between 0.416 and 0.999 .

Using these criteria, we found 5 factors. The results of EFA are presented in Table 2. Enough factors to meet a specified percentage of variance explained. In this study, the extracted factors explained $77.307 \%$ of the total variance in the original variables. $75 \%$ or more variance explained recommended by many researchers [15].

Reliability is an assessment of the degree of consistency between multiple measurements of a variable [13]. A commonly used measure of reliability is internal consistency, which applies to the consistency among the variables in a summated scale [13] Cronbach's alpha is the most widely used measure to assess the internal consistency of the entire scale [13]. Cronbach's alpha values of 0.7 to 0.8 are regarded as satisfactory [13]. In this study, the minimum is 0.788 . We can conclude that all latent constructs have satisfactory internal consistency, as all scores had $a>0.7$.

\section{Results}

There are six conditions for ANOVA (analysis of variance) test. First, dependent variable should be measured at the interval or ratio level (i.e., they are continuous). Second, independent variable should 
$<$ Table $7>$ Results of ANOVA Test (Gender)

\begin{tabular}{|c|c|c|c|c|c|c|}
\hline & & Sum of Squares & $\mathrm{df}$ & Mean Square & $\mathrm{F}$ & Sig. \\
\hline Overload & $\begin{array}{l}\text { Between Groups } \\
\text { Within Groups } \\
\text { Total }\end{array}$ & $\begin{array}{c}4.008 \\
1176.901 \\
1180.909\end{array}$ & $\begin{array}{c}1 \\
633 \\
634 \\
\end{array}$ & $\begin{array}{l}4.008 \\
1.859\end{array}$ & 2.156 & .143 \\
\hline Invasion & $\begin{array}{l}\text { Between Groups } \\
\text { Within Groups } \\
\text { Total }\end{array}$ & $\begin{array}{c}.086 \\
1277.709 \\
1277.795\end{array}$ & $\begin{array}{c}1 \\
633 \\
634 \\
\end{array}$ & $\begin{array}{c}.086 \\
2.018\end{array}$ & .042 & .837 \\
\hline Complexity & $\begin{array}{l}\text { Between Groups } \\
\text { Within Groups } \\
\text { Total }\end{array}$ & $\begin{array}{c}332 \\
969.101 \\
969.433\end{array}$ & $\begin{array}{c}1 \\
633 \\
634 \\
\end{array}$ & $\begin{array}{c}.332 \\
1.531\end{array}$ & .217 & .642 \\
\hline Insecurity & $\begin{array}{l}\text { Between Groups } \\
\text { Within Groups } \\
\text { Total }\end{array}$ & $\begin{array}{c}1.122 \\
1138.049 \\
1139.172\end{array}$ & $\begin{array}{c}1 \\
633 \\
634 \\
\end{array}$ & $\begin{array}{l}1.122 \\
1.798\end{array}$ & .624 & .430 \\
\hline Uncertainty & $\begin{array}{l}\text { Between Groups } \\
\text { Within Groups } \\
\text { Total }\end{array}$ & $\begin{array}{c}9.156 \\
975.412 \\
984.568\end{array}$ & $\begin{array}{c}1 \\
633 \\
634 \\
\end{array}$ & $\begin{array}{l}9.156 \\
1.541\end{array}$ & 5.942 & .015 \\
\hline
\end{tabular}

consist of two or more categorical, independent groups. Typically, a one-way ANOVA is used when you have three or more categorical, independent groups, but it can be used for just two groups (but an independent-samples t-test is more commonly used for two groups). Third, there is no relationship between the observations in each group or between the groups themselves (independence of observations). Forth, there should be no significant outliers. Outliers are simply single data points within your data that do not follow the usual pattern. Fifth, dependent variable should be approximately normally distributed for each category of the independent variable. Finally, there needs to be homogeneity of variances.

We carried out ANOVA analysis (Analysis of Variance) to test the significance of overall differences across two groups and to investigate the overall significance of technostress differences across the two groups. We followed with pairwise comparisions of group difference, targeting the significance of technostress differences between two groups.

We split the sample into two groups based on demographic variables: gender and position. Gender was recorded 1 if the respondent is male and 0 for female. Position was recorded as 1 if the respondent is manager and 0 for employee. Next, we conducted an

$<$ Table $8>$ Results of ANOVA Test (Position)

\begin{tabular}{|c|c|c|c|c|c|c|}
\hline & & Sum of Squares & $\mathrm{df}$ & Mean Square & $\mathrm{F}$ & Sig. \\
\hline Overload & $\begin{array}{l}\text { Between Groups } \\
\text { Within Groups } \\
\text { Total }\end{array}$ & $\begin{array}{c}13.247 \\
1167.662 \\
1180.909\end{array}$ & $\begin{array}{c}1 \\
633 \\
634 \\
\end{array}$ & $\begin{array}{c}13.247 \\
1.845\end{array}$ & 7.181 & .008 \\
\hline Invasion & $\begin{array}{l}\text { Between Groups } \\
\text { Within Groups } \\
\text { Total }\end{array}$ & $\begin{array}{c}2.461 \\
1275.334 \\
1277.795\end{array}$ & $\begin{array}{c}1 \\
633 \\
634 \\
\end{array}$ & $\begin{array}{l}2.461 \\
2.015\end{array}$ & 1.221 & .269 \\
\hline Complexity & $\begin{array}{l}\text { Between Groups } \\
\text { Within Groups } \\
\text { Total }\end{array}$ & $\begin{array}{c}.299 \\
969.134 \\
969.433\end{array}$ & $\begin{array}{c}1 \\
633 \\
634 \\
\end{array}$ & $\begin{array}{c}.299 \\
1.531\end{array}$ & .195 & .659 \\
\hline Insecurity & $\begin{array}{l}\text { Between Groups } \\
\text { Within Groups } \\
\text { Total }\end{array}$ & $\begin{array}{c}.024 \\
1139.148 \\
1139.172\end{array}$ & $\begin{array}{c}1 \\
633 \\
634 \\
\end{array}$ & $\begin{array}{c}.024 \\
1.800\end{array}$ & .013 & .909 \\
\hline Uncertainty & $\begin{array}{l}\text { Between Groups } \\
\text { Within Groups } \\
\text { Total }\end{array}$ & $\begin{array}{c}12.617 \\
971.950 \\
984.568\end{array}$ & $\begin{array}{c}1 \\
633 \\
634 \\
\end{array}$ & $\begin{array}{l}12.617 \\
1.535\end{array}$ & 8.217 & .004 \\
\hline
\end{tabular}


ANOVA to examine how stress levels differed from the intensity of individual stressor components. The results are shown in Table 3, Table 4, Table 5, Table 6, Table 7, and Table 8.

Results are shown below. It begins with descriptive statistics and the results of the test for homogeneity of variance, ending with the familiar ANOVA summary table. The key information is the $\mathrm{F}$-ratio and associated probability.

The Levene test tests the assumption that the group variances are homogenous. When the results of this test are significant, that is, the "2-tail Sig." is less than .05, the assumption has been violated. The solution involves adjusting the degrees of freedom for finding the critical value of $\mathrm{F}$.

This nonsignificant result is good because it shows that the homogeneity of variance assumption was not violated. A "Sig." value below .05 would be a cause for concern.

This is the table that shows the output of the ANOVA analysis and whether we have a statistically significant difference between our group means.

\section{Conclusions and Implications}

Stress has assumed particular importance because of the rapid technological changes facing today's organizations [6]. Along with generating obvious payback for organizations in terms of reduced operational costs, greater process efficiencies, new strategic alternatives, and possibilities for innovation, ICTs can also cause negative reactions in individuals and require them to adjust in various ways [23]. This phenomenon, termed technostress, has been attributed to an inability to adapt or cope with new ICTs in a healthy manner [23]. Technostress arouses a variety of outcomes such as dissatisfaction, fatigue, anxiety, tension, and overwork, leading to a negative effect on individual productivity [23]. Thus, the effect of ICTs on stress in individuals is an important area of inquiry that has so far not been adequately addressed [23]. This paper investigates answers to the question: "How technostress varies across individuals".

Our results confirm that gender and level of position differences exist. Specifically, we found that men experience more technostress than women. In general, women tend to use ICTs when they have to whereas men are more inclined to use ICTs when they want to [25]. Where use was voluntary, men were more inclined to use ICTs and hence experienced a higher intensity of technostress than women [25]. We also discovered that employees experience less technostress because they are likely to have more ability to handle the disruptions arising from technostress.

\section{REFERENCES}

[1] Arnetz, B. B., Wiholm, C., Technological Stress Psychophysiological Symptoms in Modern Offices, Journal of Psychosomatic Research, vol. 43, no. 1, pp. 35-42, 1997.

[2] Ayyagari, R., Grover, V., and Purvis, R., Technostress: Technological Antecedents and Implications, MIS Quarterly, vol. 35, no. 1, pp. 831-858, 2011.

[3] Bitchteler, J., Technostress in Libraries: Cause, Effects and Solution, Electronic Library, vol. 5, no, 5, pp. 282-287, 1987.

[4] Brillhart, P. E., Technostress in the Workplace: Managing Stress in the Electronic Workplace, Journal of American Academy of Business, pp. 302-307, 2004.

[5] Brod, C., Managing Technostress: Optimizing the Use of Computer Technology, Personnel Journal, vol. 61, pp. 753-757, 1982.

[6] Caro, D. H. J., and Sethi, A. S., Strategic Management of Technostress: The Chaining of Prometheus, Journal of Medical Systems, vol. 9, no. 5/6, pp. 291-304, 1985.

Journal of Digital Convergence I 25 
[7] Champion, S., Technostress: Technology's Toll, School Library Journal, pp. 48-51, 1988.

[8] Chi, S., Das, S., and Rao, H. R., Factors Affecting Bloggers' Knowledge Sharing: An Investigation Across Gender, Journal of MIS, vol. 28, no. 3, pp.309-341, 2012.

[9] Costello, A. B., and Osborne, J. W., Best Practices in Exploratory Factor Analysis: Four Recommendations for Getting the Most from Your Analysis, Practical Assessment, Research \& Evaluation, vol. 10, no. 7, pp. 1-9, 2005.

[10] Eagly, A. H., and Wood, W., Explaining Sex Differences in Social Behavior: A Meta-Analytic Perspective, Personality \& Social Psychology Bulletin, vol. 17, no. 3, pp.306-315, 1991.

[11] Fabrigar, L. R., Wegener, D. T., MacCallum, R. C., and Strahan, E. J., Evaluating the Use of Exploratory Factor Analysis in Psychological Research, Psychological Methods, vol. 4, no. 3, pp. 272-299, 1999.

[12] Franke, G. R., Crown, D. F., and Spake, D. F., Gender Differences in Ethical Perceptions of Business Practices: A Social Role Theory Perspective, Journal of Applied Psychology, vol. 82, no. 6, pp. 920-934, 1997.

[13] Hair, J. F., Black, W. C., Babin, B. J., Anderson, R. E., and Tatham, R. L., Multivariate Data Analysis, $6^{\text {th }}$ eds., Pearson Education International, Upper Saddle River, New Jersey, 2006.

[14] Hayton, J. C., Allen, D. G., and Scarpello, V., Factor Retention Decisions in Exploratory Factor Analysis: A Tutorial on Parallel Analysis, Organizational Research Methods, vol. 7, no. 2, pp. 191-205, 2004.

[15] Henson, R. K., and Roberts, J. K, Use of Exploratory Factor Analysis in Published Research Common Errors and Some Comment on Improved Practice, Educational and Psychological Measurement, vol. 66, no. 3, pp. 393-416, 2006.

[16] Kahn, J. H., Factor Analysis in Counseling Psychology Research, Training, and Practice:
Principles, Advances, and Applications, Counseling Psychologist, vol. 34, no. 5, pp. 684-718, 2006.

[17] Kite, M. E., Stockdale, G. D., Whitley, Jr., B. E., and Johnson, b. T., Attitudes toward Younger and Older Adults: An Updated Meta-Analytic Review, Journal of Social Issues, vol. 61, no. 2, pp. 241-266, 2005.

[18] Lin, X., Li, Y., Califf, C. B., and Featherman, M. Can Social Role Theory Explain Gender Differences in Facebook Usage, $46^{\text {th }}$ Hawaii International Conference on System Sciences, pp. 690-699,2013.

[19] O’Brien, K. E., Biga, a., Kessler, S. R., and Allen, T. D., A Meta-Analytic Investigation of Gender Differences in Mentoring, Journal of Management, vol. 36, pp. 537-554, 2010.

[20] Ragu-Nathan, T. S., Tarafdar, M., Ragu-Nathan, B. S., and Tu, Q., The Consequences of Technostress for End Users in Organizations: Conceptual Development and Empirical Validation, Information Systems Research, vol. 19, no. 4, pp. 417-433, 2008.

[21] Sethi, V., King, R. C., and Quick, J. C., What Causes Stress in Information System Professionals?, Communications of the ACM, vol. 47, no. 3, pp. 99-102, 2004.

[22] Shu, Q., Tu, Q., and Wang, K., The Impact of Computer Self-Efficacy and Technology Dependence on Computer-Related Technostress: A Social Cognitive Theory Perspective, International Journal of Human-Computer Interaction, vol. 27, no. 10, pp. 923-939, 2011.

[23] Tarafdar, M., Tu, Q., Ragu-Nathan, B. S., and Ragu-Nathan, T. S., The Impact of Technostress on Role Stress and Productivity, Journal of Management Information Systems, vol. 24, no. 1, pp. 301-328, 2007.

[24] Tarafdar, M., Tu, Q., and Ragu-Nathan, T. S., Impact of Technostress on End-User Satisfaction and Performance, Journal of Management Information Systems, vol. 27, no. 3, pp. 303-334, 2011. 
[25] Tarafdar, M., Tu, Q., Ragu-Nathan, T. S., and Ragu-Nathan, B. S., Crossing to the Dark Side: Examining Creators, Outcomes, and Inhibitors of Technostress, Communications of the ACM, vol. 54, no. 9, pp. 113-120, 2011.

[26] Tinsley, H. E. A., and Tinsley, D. J., Uses of Factor Analysis in Counseling Psychology Research, Journal of Counseling Psychology, vol. 34, no. 4, pp. 414-424, 1987.

[27] Sankar, Y., and Natale, S. M., Technological Change, Technostress, and Industrial Humanism, International Journal of Value Based Management, vol. 3, no. 1, pp. 91-103, 1990.

[28] Tu, Q., Wang, K, and Shu, Q., Computer-Related Technostress in China, Communications of the ACM, vol. 48, no. 4, pp. 77-81, 2005.

[29] Wang, K., Shu, Q., and Tu, Q., Technostress under

Different Organizational Environments: An Empirical Investigation, Computers in Human Behavior, vol. 24, pp. 3002-3013, 2008.

임 명 성(Yim, Myung-Seong)

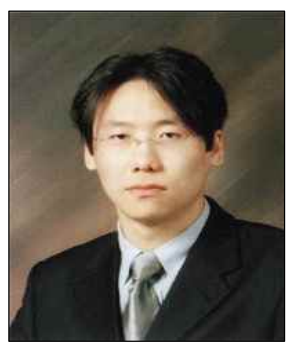

- 2002년 2월 : 삼육대학교 경영정보 학과(경영 학사)

- 2004년 2월 : 한국외국어대학교 경 영정보대학원(경영학 석사)

- 2011년 8월 : 서강대학교 경영전문 대학원(경영학 박사)

- 2011년 8월 2012년 2월 : 서강대

학교 경영학부 대우교수

- 2012년 3월 현재 : 삼육대학교 경영학과 조교수

- 관심분야 : 정보보안, 서비스 시스템, 정보 심리학, 연구 방 법론

•E-Mail : msyim@syu.ac.kr 